material sacrifice of rapidity of action. This can only be done by altering the permanent connections underneath the stand of the relay. The terminals $\mathrm{D}^{\prime}$ and $\mathrm{U}^{\prime}$ are joined to each other by a brasss strap. Care must be taken to join the terminal $D$ to the zinc pole of the battery. The electromagnetic switch $\mathrm{K}$ is simply an ordinary electric bell relay: it is used in order to avoid passing a strong current through the delicate relay $R$. The lamp $L$ is an 8-volt lamp of 5 -candle power. The battery $\mathrm{C}$ consists of 5 bichromate or Grove cells ; secondary cells, if available, would of course be much better.

The connections being made as above, it only remains to adjust the relay. The platinum contacts must be clean and smooth; those in my instrument are occasionally cleaned with a watchmaker's "dead smooth" file, and then rubbed with a bright knitting-needle. The two stops are screwed up until there is only just room for the tongue to move between them. The milled head $F$, is first turned clock-wise, so as to make the tongue press against the $M$ stop, and then (the selenium cell being in the dark, or only feebly illuminated) it is slowly and cautiously turned counter-clockwise, until the tongue passes over to the $\mathrm{S}$ stop, which causes the lamp to be switched on. If now the selenium cell is exposed to a sufficiently strong light, the tongue moves back to the $M$ stop, owing to the increased current through the magnet-coils, and the lamp goes out. It is possible to adjust the relay so that the lamp is lighted automatically whenever the external illumination falls below any desired degree of intensity, and the adjustment when once properly effected, will remain perfect for days or weeks together.

The selenium-cell is made by winding two fine copper wires, which serve as electrodes, very close together around a slip of mica, one surface of which is afterwards coated with a thin film of selenium. I have given full instructions for the manufacture of these cells in NATURE, vol. xxiii. p. 58 , and need not repeat them here. The cell used for the lamp experiment measures $2 \frac{1}{4}$ inch by $\frac{3}{4}$ inch; the gauge of the copper wires is No. 36 , and each wire makes 20 turns to the inch. The resistance of the cell in the dark is about 52,000 ohms.

The experiment may be shown by placing the cell near a window, and closing the shutters, when the lamp immediately lights up, going out again as soon as the shutters are reopened. When daylight is not available, the effect may be exhibited in a scarcely less striking way by alternately screening and exposing a gas burner placed at a distance of a foot or two from the selenium, or by turning the gas up and down. The following test illustrates the sensitiveness of the arrangement. The relay was adjusted so that the lamp circuit was just closed when a standard candle was burning at a distance of $7 \frac{1}{2}$ inches from the selenium-cell. The candie was moved slowly towards the cell, until the distance between them was reduced to $6 \frac{1}{2}$ inches, when the increased illumination caused the lamp circuit to be broken. The candle was then moved back, and when the distance was once more $7 \frac{1}{2}$ inches, the circuit was again closed. By moving the candle backwards and forwards over a range of about I inch, the circuit could be alternately closed and broken as often as desired. The extreme difference in the strength of the currents passing through the selenium under these changes of illumination was shown by the galvanometer to be rather less than o'I milliampere.

Though the apparatus does not at present claim to be anything more than a pretty scientific toy, it is possible that it may turn out to be of some practical utility. To demonstrate its capabilities, I one day left the seleniumcell near the window, with the batteries joined up. At about 4 p.m., just when reading was becoming impossible through failing daylight, the lamp (which I had in fact forgotten all about) was automatically turned on.

SHELFORD BIDWELL.

\section{REMARKABLE ANCIENT SCULPTURES FROM NORTH-WEST AMERICA.}

$\mathrm{M}^{\mathrm{R}}$

R. JAMES TERRY has just published descriptions and photographs of some of the most remarkable works of prehistoric man yet discovered on the American continent. The title of his paper is sufficiently startling, but it is fully borne out by the beautiful full-size and halfsize photographic prints with which it is illustrated. They represent three rude, yet bold, characteristic, and even life-like sculptures of simian heads, executed in basalt. One of these belongs to the author, one to Mr. T. Condon, and the third to Prof. O. C. Marsh, who referred to it, in his address "On Vertebrate Life in America," in the following terms :- "On the Columbia River I have found evidence of the former existence of inhabitants much superior to the Indians at present there, and of which no tradition remains. Among many stone carvings which I saw, there were a number of heads which so strongly resembled those of apes that the likeness at once suggests itself. Whence came these sculptures and by whom were they made?" Unfortunately we have no detailed information as to the conditions under which these specimens were found, except that "they would be classed as 'surface finds,' from the fact that the shifting sand-dunes, which were largely utilized for burial purposes, are continually bringing them to the surface and exposing them." This gives no indication of their antiquity, but is quite compatible with any age which their other characteristics may suggest.

The size of the heads varies from eight to ten inches in total height, and from five and three-quarters to six and a half inches in width. The three are so different from each other that they appear to represent three distinct animals; and, so far as I can judge, they all differ considerably from the heads of any known anthropoid apes. In particular, the nostrils are much farther from the eyes and much nearer to the mouth than in any of the apes. In this respect they are more human; yet the general form of the head and face, the low and strongly-ridged forehead, and the ridges on the head and cheeks seem to point to a very low type of anthropoid. In a letter to Mr. Terry, Mr. Condon suggests "that they were copied from the figure-head of some Malay proa that may have been wrecked on the coast ;" but such a supposition is quite inadmissible, since nothing at all resembling these heads is ever carved on Malay proas, and there is no reason to believe that if such a carving did come into the possession of the natives they would ever think of copying it in stone ; while these sculptures were found two hundred miles from the coast on the east side of the Cascade Mountains.

Taking into consideration the enormous antiquity of the stone mortars and human remains found in the auriferous gravels of California buried under ancient lava streams and associated with a flora and fauna altogether different from that of any part of America at the present time, Mr. Terry's own conclusion appears the more probable. It is, "either that the animals which these carvings represent once existed in the Columbia valley, or that, in the remote past, a migration of natives from some region containing these monkeys reached this valley, and left one of the vivid impressions of their former surroundings in these imperishable sculptures." The latter alternative appears to me, for many reasons, to be bighly improbable; and though the former will seem to many persons to be still more improbable, I am inclined provisionally to accept it.

\section{ALFRED R. WALLACE.}

$x$ "Sculptured Anthropoid Ape Heads found in or near the Valley of the John Day River, a tributary of the Columbia River, Oregon." By James Terry. (New York, r8gr.) 